DOI 10.14746/ps.2014.1.35

\title{
Sprawozdanie z ogólnopolskiej konferencji naukowej „Dziennikarstwo w obliczu konfliktu zbrojnego"
}

9 stycznia 2014 r. na Wydziale Nauk Politycznych i Dziennikarstwa Uniwersytetu im. Adama Mickiewicza w Poznaniu miała miejsce konferencja poświęcona problematyce dziennikarstwa w obliczu konfliktu zbrojnego. Została zorganizowana przez najstarsze koło naukowe działające na tym wydziale - Studenckie Koło Naukowe Politologów i Dziennikarzy. Jego przewodniczącą, a zarazem główną inicjatorką wspomnianej konferencji była pani Dorota Królak. U podstaw organizacji konferencji legło słuszne założenie, że konflikty zbrojne, wojny, kryzysy, są w dzisiejszych realiach bardzo ważnym i częstym elementem przekazu medialnego. $Z$ tego powodu - co znalazło potwierdzenie w trakcie dyskusji - analiza sposobu czy też treści tych przekazów, jest ciekawą materią badawczą dla dziennikarzy, medioznawców, a także politologów.

Wydarzenie rozpoczęło się od przywitania gości przez opiekuna koła naukowego, prof. dr. hab. Macieja Walkowskiego. Zauważył on, że konferencja ta kładzie nacisk na powiązania między konfliktami zbrojnymi, bezpieczeństwem z nimi związanym oraz relacjami i przekazywaniem informacji do państw trzecich. Podkreślił również fakt, iż na konferencję zgłosiło się bardzo dużo osób z całej Polski, a wybrane mogły zostać tylko najbardziej wartościowe referaty.

Ta ogólnopolska konferencja podzielona została na trzy panele, w trakcie których wynikami swoich badań i prac naukowych podzielić mogli się zarówno studenci, jak i bardziej doświadczeni pracownicy naukowi, a także praktycy związani z relacjonowaniem wydarzeń związanych z konfliktami zbrojnymi. W pierwszym panelu uwagę mógł zwrócić fakt, iż wiele wystąpień zwracało uwagę na czynnik ludzki w opisywanym problemie. W swoim wystapieniu mgr Michał Brydak z Uniwersytetu Rzeszowskiego szczegółowo przybliżył sylwetkę sławy amerykańskiego dziennikarstwa Larry’ego Burrowsa. Postać ta uświadomiła słuchaczom konferencji jak wiele zmieniło się w postrzeganiu konfliktów na świecie od czasu amerykańskiej wojny w Wietnamie. Zmianę tę pozwoliła zobrazować również Aleksandra Golus, która w bardzo interesujący sposób przedstawiła problematykę związaną z ograniczeniem przekazu dla amerykańskiej opinii publicznej w trakcie operacji Just Cause, czyli inwazji Stanów Zjednoczonych na Panamę.

Drugim elementem poruszanym podczas pierwszego panelu był obiektywizm przekazu medialnego. Prelegenci opisywali i analizowali poszczególne przypadki, starając się zdefiniować takie pojęcia jak obiektywizm przekazu czy dziennikarstwo zaangażowane. Zaprezentowane zostały przykłady operacji wojskowych, których realizacja została zmieniona ze względu na wcześniejszy obraz medialny wykreowany przez korespondentów zagranicznych.

Ostatnim elementem pierwszego panelu była prelekcja Michała Staniula, który jest dziennikarzem stale współpracującym z portalem internetowym „Wirtualna Polska”, ale publikującym swoje artykułu również w takich tygodnikach jak „Polityka” czy „Tygodnik Powszechny". W trakcie jego wystąpienia zebrani goście mogli wysłuchać zarówno chłodnego, praktycznego spojrzenia na relacjonowanie konfliktów zbrojnych, jak i odniesień do wcześniejszych wystąpień, do których M. Staniul nawiązywał również pod kątem nauko- 
wym. Pierwszy panel zakończył się długą dyskusją i wymianą poglądów pomiędzy dziennikarzem i studentami oraz młodymi naukowcami biorącymi udział w pierwszym panelu.

Panel drugi konferencji stanowiło wystapienie dr. Piotra Ebbiga z Uniwersytetu Ekonomicznego w Poznaniu, mające niemal charakter spotkania autorskiego. Jak można było się przekonać jest on nie tylko podróżnikiem, ale i wnikliwym obserwatorem świata. Podczas prelekcji podzielił się swoimi fotograficznymi refleksjami z różnych zakątków globu oraz przybliżył współczesne pojęcie fotografii dokumentalnej. Stanowiło to okazję by móc wysłuchać autorskich i niewątpliwie subiektywnych opowieści, oglądając zdjęcia z krajów Ameryki Środkowej, Albanii, Naddniestrza, Libanu czy Włoch dotkniętych trzęsieniem ziemi w 2009 r., które zostały specjalnie na potrzeby konferencji wybrane przez Gościa z olbrzymich zbiorów.

Wystapienie dr. Roberta Czuldy z Uniwersytetu Łódzkiego rozpoczęło ostatni, trzeci panel konferencji. Jest on autorem licznych artykułów dla czasopism „Stosunki Międzynarodowe”, „Wprost”, „Polska Zbrojna”, a w murach Wydziału Nauk Politycznych i Dziennikarstwa UAM przybliżył uczestnikom wydarzenia ewolucje relacji pomiędzy wojskiem a mediami od czasu wojny w Wietnamie do II wojny w Zatoce Perskiej. Wychodząc w swoich tezach od słynnego stwierdzenia Hirama Johnsona, iż ,pierwszą ofiarą wojny jest prawda" poruszony został również istotny problem manipulacji rzeczywistością podczas konfliktu. Znaczenie powiązań i wpływów pomiędzy wybranymi przez prelegentów elementami było aspektem wspólnym panelu trzeciego. Poruszono bowiem szereg zagadnień jak terroryzm a środki masowego przekazu, rola fotografa w demityzacji obrazu wojny, czy rola mediów w odniesieniu do międzynarodowych konfliktów lat 90., którą przedstawiła w swoim wystapieniu Magdalena Karkulak z Uniwersytetu Wrocławskiego, prezentując koncepcję efektu CNN na przykładzie wojny w Zatoce Perskiej, Somalii oraz Kosowa.

Ogólnopolska konferencja naukowa „Dziennikarstwo w obliczu konfliktu zbrojnego” zgodnie z założeniem organizatorów odbiegała od znanej studentom klasycznej, czysto naukowej formy konferencji. Zaproszeni goście mogli opowiedzieć słuchaczom o własnych doświadczeniach związanych z pobytem w konfliktowych rejonach świata, a studenci zaprezentować swoje wystapienia stanowiące wyraz ich zainteresowania tematyką. W ten sposób organizatorzy konferencji ukazali wspólną płaszczyznę zainteresowań dla dziennikarzy, medioznawców, jak i politologów. Konferencja z uwagi na ciekawą formułę oraz kameralny charakter stanowiła znakomite forum dyskusji i wymiany poglądów. Uczestnicy wyrazili przekonanie, iż pogłębiona refleksja nad rolą dziennikarstwa w konfliktach zbrojnych jest potrzebna w dyskursie zarówno akademickim, jak i publicznym.

Patryk JĘDROWIAK Krzysztof GRZĄDZIELSKI 